\title{
PENGARUH KEPEMIMPINAN KYAI DAN ETOS KERJA USTADZ/USTADZAH TERHADAP KOMPETENSI PENGAJAR DI PONDOK PESANTREN QOTRUN NADA KOTA DEPOK
}

\author{
Humaidi Mufa (humaidimufa@gmail.com) \\ Mohamad Jaenudin, Amie Primarni \\ Program Pascasarjana \\ Institut Agama Islam Nasional (IAI-N) Laa Roiba Bogor
}

\begin{abstract}
The purpose of this study is; (1) To study and analyze the influence of clerical leadership and the work ethic of cleric / cleric to the professional competence of teachers at the Qotrun Nada Islamic Boarding School Depok jointly, (2) the influence of the cleric leadership on the Teacher Competence at the Qotrun Nada Islamic Boarding School in Depok, (3) the influence of the work ethic of the cleric / cleric to the Teacher Competence at the Qotrun Nada Islamic Boarding School in Depok, (4) which is more influential between the clerical leadership or the work ethic of the cleric / cleric to the Teacher Competence at the Qotrun Nada Islamic Boarding School in Depok.

The method used in this research is quantitative descriptive method. The sample taken is the whole population. The data analysis technique used is multiple linear regression analysis.

From the results of the study it was found that the influence of the kyai's leadership on Teacher Competence at Qotrun Nada Islamic Boarding School was not too significant. This is evidenced by the $t$ test value, sig value of $0.136<0.05$ then Ho is accepted and Ha is rejected. There is an influence of ustadz / ustadzah's work ethic on Teacher Competence at Qotrun Nada Islamic Boarding School. This is evidenced by the t test value, sig value 0,000 <0.05 then Ho is rejected and Ha is accepted. The leadership of the kya and the work ethic of the cleric / cleric contributed concurrently to the Teacher Competence at Qotrun Nada Islamic Boarding School at 52.8\%, this was evidenced by the f test.
\end{abstract}

Keywords: clerical leadership, teacher competence, work ethic.

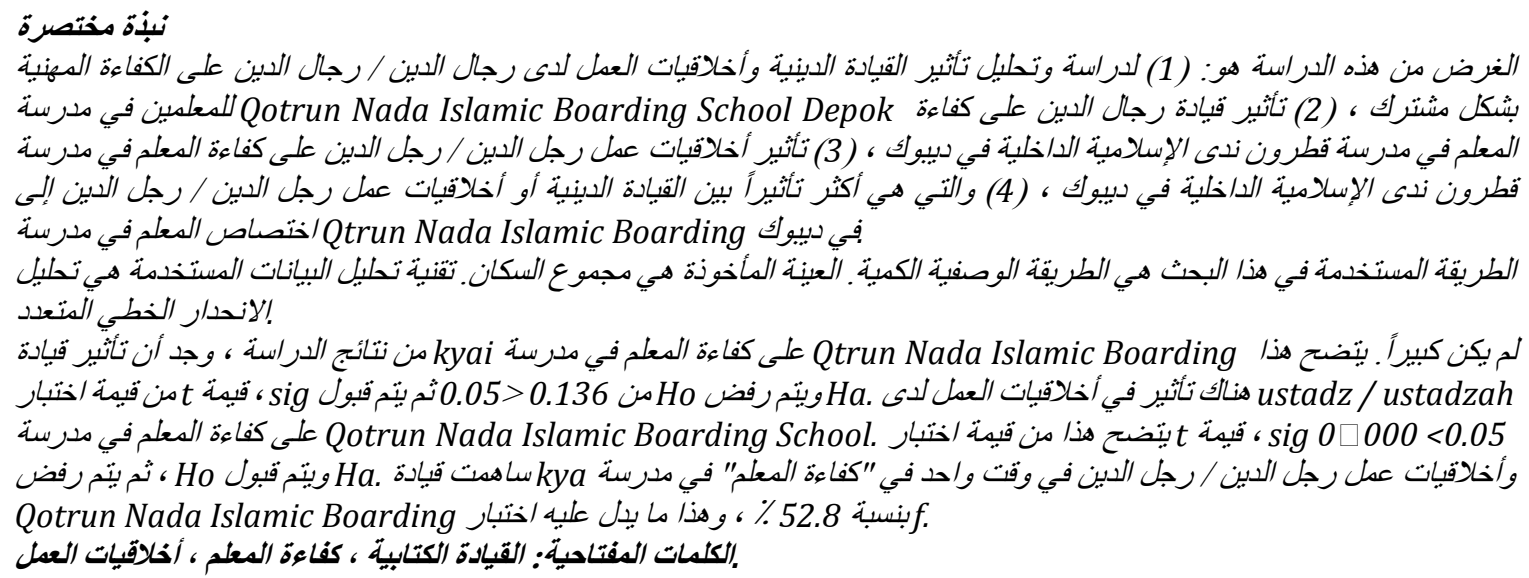




\begin{abstract}
ABSTRAK
Tujuan penelitian ini adalah; (1) Untuk mengkaji dan menganalisis pengaruh kepemimpinan kyai dan etos kerja ustadz/ustadzah terhadap kompetnsi profesional pengajar di Pondok Pesantren Qotrun Nada Depok secara bersama-sama, (2) pengaruh kepemimpinan kyai terhadap Kompetensi Pengajar di Pondok Pesantren Qotrun Nada Depok, (3) pengaruh etos kerja ustadz/ustadzah terhadap Kompetensi Pengajar di Pondok Pesantren Qotrun Nada Depok, (4) mana yang lebih berpengaruh antara kepemimpinan kyai atau etos kerja ustadz/ustadzah terhadap Kompetensi Pengajar di Pondok Pesantren Qotrun Nada Depok. Metode yang digunakan dalam penelitian ini adalah metode deskriptif kuantitatif. Sampel yang diambil adalah keseluruhan populasi. Teknik analisis data yang digunakan adalah analisis regresi linier berganda. Dari hasil penelitian didapatkan hasil, bahwa pengaruh kepemimpinan kyai terhadap Kompetensi Pengajar di Pondok Pesantren Qotrun Nada tidak terlalu signifikan. Hal ini dibuktikan dengan nilai uji t, nilai sig 0,136<0,05 maka Ho diterima dan Ha ditolak. Ada pengaruh etos kerja ustadz/ustadzah terhadap Kompetensi Pengajar di Pondok Pesantren Qotrun Nada. Hal ini dibuktikan dengan nilai uji t, nilai sig 0,000< 0,05 maka Ho ditolak dan Ha diterima. Kepemimpinan kya dan etos kerja ustadz/ustadzah berkontribusi bersamaan terhadap Kompetensi Pengajar di Pondok Pesantren Qotrun Nada sebesar 52,8\%, hal ini dibuktikan dengan uji f.
\end{abstract}

Kata kunci : etos kerja, kepemimpinan kyai, kompetensi pengajar.

\title{
A. PENDAHULUAN
}

Dari tahun ke tahun, Pondok Pesantren Qotrun Nada semakin berkembang dan semakin pesat, yang hingga saat ini tercatat lebih dari 1800 santri yang menimba ilmu di pondok pesantren Qotrun Nada, mereka seluruhnya mukim di pondok. Mereka berasal dari berbagai daerah antara lain Jambi, Padang, Pekalongan, Gresik, Tangerang, Jakarta, Bogor, Bekasi, Medan dan masyarakat sekitar pondok pesantren itu sendiri Jabodetabek.

Populasi santri yang begitu banyak juga membuat Pondok Pesantren Qotrun Nada ini menyiapkan tenaga pengajar yang juga tidak sedikit yakni sebanyak 150 pengajar, bahkan sebagian besar dari pengajar tetap standby di Pondok Pesantren setiap hari selama 24 jam ${ }^{1}$.

Seperti dikemukakan oleh Arifin keberadaan seorang Kiai sebagai pemimpin di pesantren ditinjau dari tugas dan fungsinya dapat dipandang sebagai fenomena kepemimpinan yang unik. Kiai sebagai pimpinan lembaga pendidikan Islam tidak sekedar bertugas menyusun kurikulum pendidikan agama Islam, membuat peraturan tata tertib, merancang sistem evaluasi, melaksanakan pembelajaran berkaitan dengan ilmu ilmu yang diajarkan di pesantren. ${ }^{2}$

Namun juga memiliki peran yang sangat demikian sentralnya, maka sosok Kiai sebagai pemimpin menurut Arifin memenuhi kriteria ideal Kiai dipercaya, ditaati, dan diteladani oleh komunitas yang dipimpinnya memiliki integritas pribadi yang tinggi terhadap kebenaran, kejujuran, dan keadilan. Kepemimpinan Kiai ditaati karena memiliki penguasaan informasi,

${ }^{1}$ Arsip Pondok Pesantren Qotrun Nada, Profil Pondok Pesantren Qotrun Nada, (Dilihat 15 Agustus 2019)

${ }^{2}$ Arifin, Imron, Kepemimpinan Kiyai: Kasus Pondok Pesantren Tebu Ireng, (Malang: Kalimashada Press, 1993), hal.8. 
keahlian profesional, dan kekuatan moral. Pesona pribadi yang ditampilkan menjadikan seorang Kiai dicintai dan dijadikan panutan sebagai figur yang diteladani dan sumber inspirasi bagi komunitas yang dipimpinnya.

Kyai berkedudukan sebagai tokoh sentral dalam tata kehidupan pesantren, sekaligus sebagai pemimpin pesantren yang bertanggungjawab secara penuh atas segala sesuatu yang terjadi didalam pondok pesantren. Dalam kedudukan ini nilai kepesantrenannya banyak tergantung pada kepribadian Kyai sebagai suri teladan dan sekaligus pemegang kebijaksanaan mutlak dalam tata nilai pesantren. Dalam hal ini M. Habib Chirzin mengatakan bahwa peran kyai sangat besar sekali dalam bidang penanganan iman, bimbingan amaliyah, penyebaran dan pewarisan ilmu, pembinaan akhlak, pendidikan beramal, dan memimpin serta menyelesaikan masalah yang dihadapi oleh santri dan masyarakat. Dan dalam hal pemikiran kyai lebih banyak berupa terbentuknya pola berpikir, sikap, jiwa, serta orientasi tertentu untuk memimpin sesuai dengan latar belakang kepribadian kyai. ${ }^{3}$

Selain itu dalam konteks pondok pesantren sebagai lembaga pendidkan juga tidak terlepas dari peranan para pengajar atau yang lebih dikenal sebagai Ustadz/Ustadzah sebagai motor penggerak segala kebijakan yang ditetapkan oleh Kyai. Masih menuut penulis Ustadz/ustadzah yang baik salah satu indikatornya adalah yang memiliki semangat/etos kerja dan focus terhadap apa yang menjadi tanggungjawabnya.

Menurut Toto Tasmara, etos kerja lebih merujuk kepada kualitas kepribadian pekerja yang dalam hal ini adalah pengajar yang tercermin melalui untuk kerja secara utuh dalam berbagai dimensi kehidupannya. Dengan demikian, etos kerja lebih merupakan kondisi internal yang mendorong dan mengendalikan perilaku pekerja kearah terwujud kualitas kerja yang ideal. Kualitas untuk kerja dan hasil kerja banyak ditentukan oleh kualitas etos kerja ini. Sebagai suatu kondisi internal, etos kerja mengandung beberapa unsur antara lain: (1) disiplin kerja, (2) sikap terhadap kerjaan, (3) kebiasaan-kebiasaan bekerja. Dengan disiplin kerja, seorang pekerja akan selalu bekerja dalam pola-pola yang konsisten untuk melakukan dengan baik sesuai tuntutan dan kesanggupannya. ${ }^{4}$

Etos kerja yang baik sangat dibutuhkan oleh setiap orang agar mampu memaksimalkan kemampuannya terhadap bidang atau profesi yang sedang digeluti. Hal ini dikarenakan pada setiap profesi membutuhkan kualitas terbaik dari pelaku profesi tersebut.

Ustadz/Ustadzah sebagai pengajar merupakan unsur sumber daya yang sangat menentukan keberhasilan pendidikan di Pondok Pesantren, karena pengajar merupakan unsur manusiawi yang sangat dekat hubungannya dengan santri (siswa) dalam upaya pendidikan sehari-hari di Pondok Pesantren. Adapun penanggung jawab keterlaksanaan proses pembelajaran di kelas adalah pengajar. Pemberdayaan terhadap mutu pengajar perlu dilakukan secara terus menerus, dan berkelanjutan. Hal tersebut tentu tidak lepas dari unsur manajemen kelas. Kualitas pengajar akan mempengaruhi keberhasilan siswa dalam belajar, yang berujung pada peningkatan kompetensi pengajar, untuk itu pengajar dituntut untuk lebih profesional dalam menjalankan tugasnya.

\footnotetext{
${ }^{3}$ Wahab, Rochidin, Sejarah Pendidikan Islam di Indonesia, (Bandung: Alfabeta CV.2004), hal.153.

${ }^{4}$ Toto Tasmara, Membudayakan Etos Kerja Islami......hlm. 73
} 
Namun disamping itu semua hal ini juga tidak memungkiri bahwa masih terdapatnya kelemahan dan kekurangan yang mengharuskan lembaga ini terus berbenah untuk memperbaikinya demi kualitas yang lebih baik lagi. Salah satu langkah pembenahan yang dilakukan adalah dengan mengadakan Briefing Pagi setiap hari sebelum memulai kegiatan belajar mengajar untuk seluruh Guru dan Jajaran Pimpinan, hal ini dilakukan guna dapat mengupdate informasi terkait perkembangan-perkembangan anak didik secara cepat dan ketika ada masalah dapat segera diatasi berdasarkan hasil musyawarah bersama, akan tetapi proses kegiatan briefing ini masih terkendala dengan harus hadirnya Kyai mendampingi proses tersebut, jika tidak maka akan tercipta kondisi dimana kurang maksimalnya pelaksanaan Briefing Pagi dihari tersebut.

Berdasarkan salah satu hasil observasi awal diatas, terdapat permasalahan di lihat dimana pimpinan pondok pesantren belum menerapkan kepemimpinan yang maksimal sehingga dapat berpengaruh terhadap Kompetensi Pengajar. Selain itu etos kerja yang tidak baik seperti guru yang kurang disiplin dan juga belum memahami akan tugas dan kewajibannya juga akan menjadi salah satu kendala dalam membentuk pengajar yang profesional. Di lihat dari permasalahan tersebut maka peneliti tertarik untuk meneliti masalah tersebut dengan mengangkat judul "Pengaruh Kepemimpinan kyai dan Etos Kerja Ustadz/Ustadzah terhadap Kompetensi Pengajar di Pondok Pesantren Qotrun Nada Kota Depok."

\section{Rumusan Masalah}

Berdasarkan identifikasi masalah yang telah dijelaskan di atas maka masalah dalam penelitian ini dapat dirumuskan sebagai berikut:

1. Apakah terdapat pengaruh Kepemimpinan Kyai terhadap Kompetensi Pengajar di Pondok Pesantren Qotrun Nada?

2. Apakah terdapat pengaruh Etos Kerja Ustadz/Ustadzah terhadap Kompetensi Pengajar di Pondok Pesantren Qotrun Nada?

3. Apakah terdapat pengaruh Kepemimpinan Pondok Pesantren dan Etos Kerja

\section{Tujuan Penelitian}

Tujuan yang ingin dicapai dalam penelitian ini adalah :

1. Untuk mengetahui pengaruh Kepemimpinan Kyai terhadap Kompetensi pengajar di Pondok Pesantren Qotrun Nada.

2. Untuk mengetahui pengaruh Etos Kerja Ustadz/Ustadzah terhadap Kompetensi pengajar di Pondok Pesantren Qotrun Nada.

3. Untuk mengetahui pengaruh antara kepemimpinan Kyai, Etos Kerja Ustadz/Ustadzah terhadap Kompetensi Pengajar di Pondok Pesantren Qotrun Nada.

\section{Hipotesis Penelitian}

Penelitian tentang pengaruh kepemimpinan kyai dan etos kerja ustadz/ustadzah terhadap Kompetensi Pengajar didasarkan pada asumsi-asumsi sebagai berikut: 
1. Kompetensi Pengajar dipengaruhi oleh kepemimpinan kyai yang berkedudukan sebagai tokoh sentral dalam tata kehidupan pesantren, sekaligus sebagai pemimpin pesantren. Dalam kedudukan ini nilai kepesantrenannya banyak tergantung pada kepribadian Kyai sebagai suri teladan dan sekaligus pemegang kebijaksanaan mutlak dalam tata nilai pesantren. Semakin konsisten dan konsekuen seorang Kiai memenuhi kriteria dan prasyarat kepemimpinan ideal, maka makin kuat pula ia dijadikan tokoh pemimpin, tidak hanya oleh komunitas pesantren yang dipimpinnya, melainkan juga oleh seluruh umat Islam maupun masyarakat luas.

2. Kompetensi Pengajar juga dipengaruhi oleh etos kerja ustadz/ustadzah, karena pada dasarnya kompetensi guru tidak akan mungkin tercapai tanpa adanya etos kerja atau semangat dari para pengajar yang ada dilembaga pendidikan tersebut. Selain itu ustadz/ustadzah adalah pelaksana dari setiap kebijakan yang ditetapkan oleh pimpinan atau kyai yang akan mengukur sebebrapa berhasilnya seorang pengajar dalam mendidik pada proses belajar mengajar.

3. Dengan demikian Kompetensi Pengajar dipengaruhi oleh kepemimpinan kyai dan etos kerja ustadz/ustadzah, oleh karena itu dapat diasumsikan bahwa semakin baik kepemimpinan kyai dan etos kerja ustadz/ustadzah maka akan semakin baik pula Kompetensi Pengajar, begitu pula sebaliknya, semakin buruk kepemimpinan kyai dan etos kerja ustadz/ustadzah maka semakin buruk pula Kompetensi Pengajar.

Dalam penelitian ini, hipotesis peneliti sebagai berikut :

1. Jika kepemimpinan kyai baik, maka Kompetensi Pengajarnya baik.

2. Jika etos kerja ustadz/ustadzahnya baik, maka Kompetensi Pengajarnya baik.

3. Jika kepemimpinan kyai dan etos kerja ustadz/ustadzahnya sama-sama baik, maka kompetensi pengajar baik.

Dalam rumusan masalah dan pemaparan yang telah diurai diatas sebagai dasar penelitian dan agar penelitian ini lebih terarah dan tidak menyimpang dari tujuan penelitian yang diharapkan maka peneliti memberi batasan masalah dari penelitian ini yakni tentang sejauh mana Pengaruh Kepemimpinan Kyai dan Etos Kerja Ustadz/Ustadzah terhadap Kompetensi Pengajar di Pondok Pesantren Qotrun Nada Kota Depok." Maka variabel bebas dan terikat dalam penelitian ini yaitu: Kepemimpinan Kyai (X1) dan Etos Kerja Ustadz/Ustadzah (X2) sebagai variabel bebas (Independent variabel). Sedangkan variabel terikat (dependent variabel) adalah Kompetensi Pengajar (Y).

\section{Kerangka Berpikir}

Kemajuan suatu lembaga pendidikan yang bermutu harus memiliki pemimpin yang merupakan pondasi untuk mencetak sumber daya manusia yang sesuai dengan kebutuhan dan perkembangan masyarakat. Selain itu etos kerja juga menjadi salah satu faktor yang menentukan keberhasilan santri karena dengan etos kerja ustadz/ustadzah yang baik dari sikap, perilaku, dedikasi, dan rasa tanggung jawab yang tinggi di harapkan santri mampu memperoleh ilmu dan pengajaran dengan baik. Faktor lain dibutuhkan tenaga pengajar (guru) profesional yang bekerja dengan semangat dan motivasi yang tinggi. 
Dengan kompetensi yang dimilikinya maka diharapkan guru dapat melakukan tugas dengan baik sebagaimana fungsi guru yaitu sebagai pengajar dan pendidik, sehingga diharapkan dapat meningkatkan kualitas pembelajaran.

Dalam rumusan masalah dan pemaparan yang telah diurai diatas sebagai dasar penelitian dan agar penelitian ini lebih terarah dan tidak menyimpang dari tujuan penelitian yang diharapkan maka peneliti memberi batasan masalah dari penelitian ini yakni tentang sejauh mana Pengaruh Kepemimpinan Kyai dan Etos Kerja Ustadz/Ustadzah terhadap Kompetensi Pengajar di Pondok Pesantren Qotrun Nada Kota Depok." Maka variabel bebas dan terikat dalam penelitian ini yaitu: Kepemimpinan Kyai (X1) dan Etos Kerja Ustadz/Ustadzah (X2) sebagai variabel bebas (Independent variabel). Sedangkan variabel terikat (dependent variabel) adalah Kompetensi Pengajar (Y).

Kerangka Pemikiran :

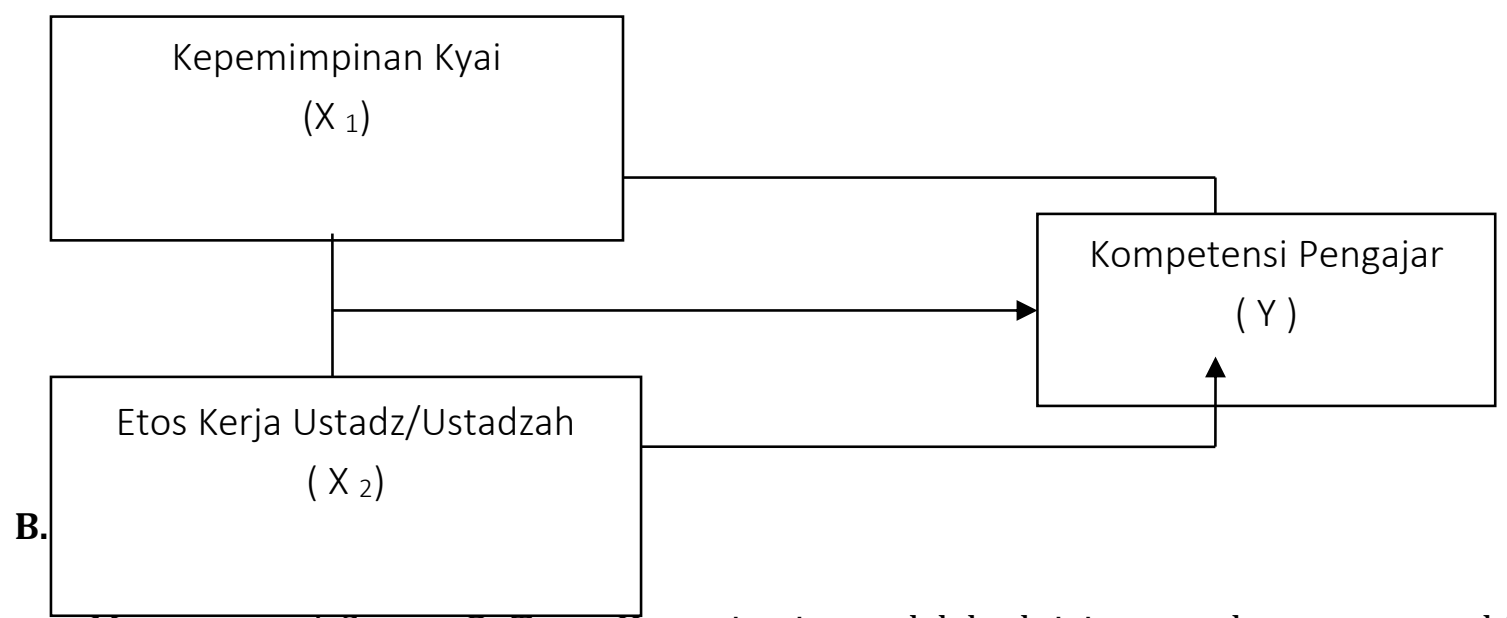

Menurut teori George R. Terry Kepemimpinan adalah aktivitas untuk mempengaruhi orang-orang supaya diarahkan mencapai tujuan organisasi. ${ }^{5}$ Seperti dikemukakan oleh Arifin keberadaan seorang Kiai sebagai pemimpin di pesantren ditinjau dari tugas dan fungsinya dapat dipandang sebagai fenomena kepemimpinan yang unik. Kiai sebagai pimpinan lembaga pendidikan Islam tidak sekedar bertugas menyusun kurikulum pendidikan agama Islam, membuat peraturan tata tertib, merancang sistem evaluasi, melaksanakan pembelajaran berkaitan dengan ilmu ilmu yang diajarkan di pesantren. ${ }^{6}$

Karena peran yang demikian sentralnya, maka sosok Kiai sebagai pemimpin menurut Arifin memenuhi kriteria ideal Kiai dipercaya, ditaati, dan diteladani oleh komunitas yang dipimpinnya memiliki integritas pribadi yang tinggi terhadap kebenaran, kejujuran, dan keadilan. Kepemimpinan Kiai ditaati karena memiliki penguasaan informasi, keahlian profesional, dan kekuatan moral. Pesona peribadi yang ditampilkan menjadikan seorang Kiai dicintai dan dijadikan panutan sebagai figur yang diteladani dan sumber inspirasi bagi komunitas yang dipimpinnya.

${ }^{5}$ Pandji Anoraga, Manajemen Bisnis, cet. Kedua, (Jakarta: PT. Rineka Cipta, 2000), hal. 182

${ }^{6}$ Arifin, Imron, Kepemimpinan Kiyai: Kasus Pondok Pesantren Tebu Ireng, (Malang: Kalimashada Press, 1993), hal.8. 
Semakin konsisten dan konsekuen seorang Kiai memenuhi kriteria dan prasyarat kepemimpinan ideal tersebut, maka makin kuat pula ia dijadikan tokoh pemimpin, tidak hanya oleh komunitas pesantren yang dipimpinnya, melainkan juga oleh seluruh umat Islam maupun masyarakat luas dalam skala regional, nasional maupun internasional. ${ }^{7}$

\section{Teori Etos Kerja Ustadz/Ustadzah}

Kata "etos" bersumber dari pengertian yang sama dengan etika, yaitu sumber-sumber nilai yang dijadikan rujukan dalam pemilihan dan keputusan perilaku. Etos kerja lebih merujuk kepada kualitas kepribadian pekerja yang tercermin melalui untuk kerja secara utuh dalam berbagai dimensi kehidupannya.

Dengan demikian, etos kerja lebih merupakan kondisi internal yang mendorong dan mengendalikan perilaku pekerja kearah terwujud kualitas kerja yang ideal. Kualitas untuk kerja dan hasil kerja banyak ditentukan oleh kualitas etos kerja ini. Sebagai suatu kondisi internal, etos kerja mengandung beberapa unsur antara lain: (1) disiplin kerja, (2) sikap terhadap kerjaan, (3) kebiasaan-kebiasaan bekerja. Dengan disiplin kerja, seorang pekerja akan selalu bekerja dalam pola-pola yang konsisten untuk melakukan dengan baik sesuai tuntutan dan kesanggupannya. ${ }^{8}$

\section{Teori Kompetensi Pengajar}

Menurut Teori Charles dalam Mulyasa mengemukakan bahwa : competence as rational performance which satisfactorily meets the objectivefor a desired condition (Kompetensi merupakan perilaku yang rasional untuk mencapai tujuan yang dipersyaratkan sesuai dengan kondisi yang diharapkan). ${ }^{9}$

Pengertian dasar kompetensi (conpetency) adalah kecakapan atau kemampuan. Dalam kamus besar bahas Indonesia dijelaskan bahwa kempetensi adalah kewenangan (kekuasaan) untuk menentukan (memutuskan) sesuatu. ${ }^{10}$

Sedangkan dalam Undang-Undang Guru dan Dosen Nomor. 14/2005 Pasal 10 ayat 1 dan Peraturan Pemerintahan Nomor. 19/2005 Pasal 28 ayat 3 yang dikutip Jamil dalam bukunya dinyatakan bahwa Kompetensi Guru meliputi Kompetensi Pedagogik, Kompetensi Kepribadian, Kompetensi Sosial dan Kompetensi pengajar ${ }^{11}$

\section{STUDI TERDAHULU}

Untuk menghindari duplikasi, peneliti melakukan penelusuran terhadap bebarapa hasil penelitian terdahulu yang berkaitan dengan masalah yang akan diteliti. Ada beberapa penelitian yang relevan dengan masalah yang akan diteliti yaitu

\footnotetext{
${ }^{7}$ Arifin, Imron ... hal.130.

8 Toto Tasmara, Membudayakan Etos Kerja Islami......hal. 73

9 E. Mulyasa, Standar Kompetensi dan Sertifikasi Guru, (Bandung: PT. Remaja Rosdakarya, 2013),
} hal. 25 .

${ }^{10}$ Petter Salim dan Yenny Salim, Kamus B.I Kontemporer, (Jakarta : Modern English Press, Edisi 3, 2002), hal. 756

11 Jamil Suprahatiningkrum, Guru Profesional : Pedoman Kinerja, Kualifikasi dan Kompetensi Guru, (Yogyakarta: Ar Ruzz Media, 2014), hal. 100. 
Muhammad Asran Dirun (2016) Tesis dengan judul: Pengaruh Kepemimpinan Kepala Sekolah dan Budaya Organisasi terhadap Kinerja Guru di SMA Se- kota Palangkaraya. Fokus dari penelitian ini adalah bagaimana gaya kepemimpinan kepala sekolah yang dapat mempengaruhi budaya organisasi dan kinerja guru sehingga berdampak pada kemajuan lembaga sekolah. Tujuan dari penelitian ini untuk menganalisis dan menguji ada tidaknya pengaruh gaya kepala sekolah dan budaya organisasi terhadap kinerja Guru di SMA se- kota Palangkaraya. Penelitian ini memerlukan data yang banyak karena sampel yang digunakan seluruh SMA di palangkaraya, sedang penelitian yang peneliti lakukan hanya di satu pondok pesantren sehingga tidak terlalu memerlukan banyak datas.

Abdul Azis (2017) dengan judul : Kepemimpinan Kiyai Sebagai Pemimpin Pendidikan Di Pondok Pesantren Nurul huda Pakandangan Barat Sumenep (Journal of Islamic Education Management ISSN: 2461-0674). Penelitian ini bertujuan untuk mengungkap peran Kiyai sebagai pemimpin pendidikan di Pondok Pesantren Nurulhuda Pakandangan Sumenep. Jenis penelitian yang digunakan dalam penelitian ini adalah penelitian kualitatif. Hasil penelitian menunjukan bahwa kiyai sebagai pemimpin pendidikan memiliki tiga peran yaitu pertama peran sebagai manajer, Pengelolaan pondok pesantren diarahkan pada pencapaian tujuan pesantren. Pengambilan keputusan dilakukan dalam forum rapat tahunan serta rapat triwulan sebagai bentuk evaluasi formatif terhadap kegiatan yang sudah dilaksanakan. kedua, peran sebagai pemimpin, Gaya kepemimpinan yang digunakan adalah partisipative leadership dengan melibatkan seluruh komponen pondok pesantren yang terdiri dari pengurus, dewan asatidz, serta perwakilan santri.dan ketiga peran sebagai pengembang kurikulum, kurikulum yang digunakan di Pondok Pesantren Nurulhuda memadukan dua kurikulum yaitu kurikulum yang menjadi ketentuan dari pemerintah dan kurikulum yang disusun sendiri. Menggunakan bahasa arab dan bahasa ingris sebagai bahasa pengantar dalam setiap pelajaran juga bahasa sehari-hari santri. Kitab kuning juga diajarkan di kelas dengan tujuan sebagai pengenalan, pemahaman, latihan, dan motivasi. Penelitian ini merupakan penelitian kualitatif dimana menganalisa dengan kalimt-kalimat sedangkan penelitian yang dilakukan peneliti adalah penelitian kuantitatif dengan menggunakan angkaangka.

Ariani Fahima (2018) Skripsi dengan judul : Pengaruh Kepemimpinan dan etos kerja terhadap produktivitas kerja di kantor yayasan dana sosial al-falah Surabaya. Tujuan dari penelitian ini adalah untuk mengetahui Pengaruh Kepemimpinan dan etos kerja terhadap produktivitas kerja secara parsial maupun secara simultan di Kantor Yayasan Dana Sosial AlFalah Surabaya. Metode yang digunakan dalam penelitian ini adalah penelitian kuantitatif jenis hipotesis asosiatif. Cara yang digunakan peneliti dalam menjawab tujuan tersebut adalah dengan menggunakan uji regresi linier berganda. Penelitian ini menggunakan metodelogi kuantitatif dengan jenis hipotesis asosiatif. Penelitian ini berlokasi di Kantor Yayasan Dana Sosial Al-Falah Surabaya dengan jumlah 35 responden. Hasil penelitian ini akan membuktikan 3 hipotesis. Hipotesis pertama menunjukkan bahwa gaya kepemimpinan (X1) terhadap produktivitas kerja (Y) berpengaruh signifikan dengan p value 0.000 dan nilai hubungan sebesar 0.725. Hipotesis kedua menunjukkan bahwa budaya kerja (X2) terhadap produktivitas kerja (Y) berpengaruh signifikan dengan $\mathrm{p}$ value 0.001 dan nilai hubungan sebesar 0.524. Hipotesis ketiga menunjukkan bahwa gaya kepemimpinan (X1) dan etos kerja 
(X2) berpengaruh terhadap produktivitas kerja (Y) berpengaruh signifikan denganp value 0.000 Model regresi yang digunakan peneliti dapat digunakan sebagai prediksi tingkat produktivitas kerja dengan gaya kepemimpinan dan etos kerja pada masa yang akan datang. Hal ini dikarenakan nilai SEE lebih kecil daripada nilai simpangan baku. Nilai SEE sebesar 5.14751 dan nilai simpangan baku sebesar 7.27988. Perbedaan penelitian ini adalah di variabel y.

\section{METODE PENELITIAN}

Penelitian ini menggunakan penelitian yang bersifat kuantitatif yang bertujuan untuk mengetahui pengaruh dua variable atau lebih yang bersifat sebab akibat, menguji teori dan analisa data dengan menggunakan statistic untuk menguji hipotesis ${ }^{12}$.

Penelitian ini bersifat kuantitatif dengan memakai pendekatan regresi berganda. Dalam studi lapangan desain penelitian dengan mengkombinasi antara pencarian literature dengan survey pengalaman lapangan di sekolah atau studi kasus. Usaha mengidentifikasi variablevariabel penelitian dan hubungan antar variable tersebut dalam suatu situasi permasalahan tertentu. Studi lapangan digunakan sebagai sarana penelitian lebih lanjut dan mendalam.

Penelitian korelasi dilakukan untuk melihat ada tidaknya dan seberapa besar ditemukan adanya korelasi positif antara dua variable atau lebih secara kuantitatif. Berdasarkan nilai kofisien korelasi, maka diprediksi arah kekuatan hubungan antara variable bebas dengan variable terikat.

Berdasarkan kutipan di atas, maka pengguna pendekatan penelitian kuantitatif dilihat dari sisi dan kegunaannya sesuai dengan penelitian yang peneliti lakukan, yaitu untuk menguji seberapa tinggi atau rendahnya pengaruh antara variable independen yaitu Kepemimpinan Kyai dan Etos Kerja Ustadz/Ustadzah terhadap variable dependen yaitu Kompetensi Pengajar. Dengan demikian dalam penelitian ini terdapat dua variable independen (variable bebas) dan satu variable dependen (variable terikat).

\section{Waktu Dan Tempat Penelitian}

Penelitian ini dilakukan pada bulan Agustus 2019 sampai bulan januari 2020. Tempat penelitian ini dilakukan di Pondok Pesantren Qotrun Nada Depok. Dengan alamat, Jalan Pondok Pesantren Qotrun Nada No. 1 Rt. 02/03, Kelurahan Cipayung Jaya, Kecamatan Cipayung, Kota Depok, Jawa Barat.

\section{Teknik Sampling}

Secara teoritis Populasi penelitian adalah sejumlah keseluruhan unit analisis, yaitu objek yang akan diteliti. Sedangkan sampel adalah sebagian atau wakil dari populasi yang diteliti. Arikunto menyatakan bahwa "di dalam sebuah penelitian, subyek penelitian merupakan sesuatu yang kedudukannya sangat sentral, karena subyek penelitian itulah data tentang variabel yang diteliti diamati". ${ }^{13}$

\footnotetext{
${ }^{12}$ Sugiono, Metode penelitian Kuantitatif, Kualitatif dan R\&D,23-24

${ }^{13}$ Suharsimi Arikunto, Metodologi Penelitian, Jakarta: Rineka Cipta , 2010 h. 107
} 
Dalam penelitian penulis menggunakan sampel seluruh dari populasi. Hal ini disebut sampel total (total sampling) dengan jumlah 150 yang diambil dari keseluruhan jumlah pengajar di Pondok Pesantren Qotrun Nada maka peneliti mengambil keseluruhan Karena agar hasil penelitian lebih akurat.

\section{Teknik Analisis Data}

Analisis data yang digunakan dalam penelitian ini meliputi analisis statistik deskriptif dan analisis korelasi untuk menguji hipotesis penelitian. Analisis statistik deskriptif digunakan untuk mendeskripsikan statistik masing-masing variabel bebas yaitu kepemimpinan kyai dan etos kerja ustadz/ustadzah. Analisis statistik deskriptif juga diperlukan untuk mengetahui nilai kecenderungan data hasil penelitian yaitu dengan jalan mengurai atau menjabarkan data-data variabel penelitian (kepemimpinan kyai, etos kerja ustadz/ustadzah dan kompetensi pengajar ).

\section{Analisis Hasil}

Data hasil pengolahan angket yang telah disebarkan seluruh pengajar di Pondok Pesantren Qotrun Nada berjumlah 150 responden dengan pernyataan-pernyataan yang berkaitan dengan kepemimpinan kyai dan etos kerja ustadz/ustadzah terhadap Kompetensi Pengajar, maka analisis deskripsi data akan menguraikan jawaban responden tertang pernyataan yang diajukan dalam masing-masing indikator variabel.

\section{Variabel Kepemimpinan Kyai}

Hasil jawaban responden tentang pernyataan yang diajukan pada variabel kepemimpinan kyai berdasarkan penelitian rata-rata keseluruhan variabel kepemimpinan kyai sebesar 4,6 dengan prosentase 93\% dengan kategori sangat baik. Adapun distribusi frekuensi yang diperoleh dari penyebaran angket tentang kepemimpinan kyai adalah:

Tabel Distribusi Frekuensi

\begin{tabular}{|r|r|r|r|r|r|}
\hline \multicolumn{2}{|c|}{ Kepemimpinan Kyai } \\
\hline \multicolumn{2}{|c|}{} & Frequency & Percent & $\begin{array}{r}\text { Valid } \\
\text { Percent }\end{array}$ & $\begin{array}{c}\text { Cumulative } \\
\text { Percent }\end{array}$ \\
\hline \multirow{4}{*}{ Valid } & 3.80 & 1 & 0.7 & 0.7 & 0.7 \\
\cline { 2 - 6 } & 3.90 & 2 & 1.3 & 1.3 & 2.0 \\
\cline { 2 - 6 } & 4,1 & 6 & 4.0 & 4.0 & 6.0 \\
\cline { 2 - 6 } & 4.10 & 2 & 1.3 & 1.3 & 7.3 \\
\cline { 2 - 6 } & 4.20 & 7 & 4.7 & 4.7 & 12.0 \\
\cline { 2 - 6 } & 4.30 & 4 & 2.7 & 2.7 & 14.7 \\
\cline { 2 - 6 } & 4.40 & 4 & 4.7 & 4.7 & 19.3 \\
\cline { 2 - 6 } & 4.50 & 15 & 10.0 & 14.7 & 34.0 \\
\cline { 2 - 6 } & 4.60 & 22 & 16.0 & 16.0 & 44.0 \\
\cline { 2 - 6 } & 4.70 & 19 & 12.7 & 12.7 & 72.7 \\
\hline
\end{tabular}




\begin{tabular}{|r|r|r|r|r|r|}
\hline \multirow{2}{*}{} & 4.90 & 13 & 8.7 & 8.7 & 81.3 \\
\cline { 2 - 6 } & 4,2 & 28 & 18.7 & 18.7 & 100.0 \\
\cline { 2 - 6 } & Total & 150 & 100.0 & 100.0 & \\
\hline
\end{tabular}

Dari hasil distribusi kuesioner tersebut dapat dilihat bahwa kepemimpinan kyai paling banyak diangka 4,2 sebanyak 28 responden atau sebesar $18,7 \%$, lalu diangka 4,7 sebanyak 24 responden atau sebesar $16,0 \%$.

\section{Variabel Etos Kerja Ustadz/Ustadzah}

Hasil jawaban responden tentang pernyataan yang diajukan pada variabel etos kerja ustadz/ustadzah berdasarkan hasil penelitian rata-rata keseluruhan variabel etos kerja ustadz/ustadzah sebesar 4,5 dengan prosentase 90,\% dengan kategori sangat baik. Adapun distribusi frekuensi yang diperoleh dari penyebaran angket tentang etos kerja ustadz/ustadzah adalah :

\begin{tabular}{|c|c|c|c|c|c|}
\hline & & Frequency & Percent & $\begin{array}{l}\text { Valid } \\
\text { Percent }\end{array}$ & $\begin{array}{l}\text { Cumulative } \\
\text { Percent }\end{array}$ \\
\hline \multirow{15}{*}{ Valid } & 3.60 & 1 & 0.7 & 0.7 & 0.7 \\
\hline & 3.70 & 2 & 1.3 & 1.3 & 2.0 \\
\hline & 3.90 & 8 & 5.3 & 5.3 & 7.3 \\
\hline & 4,0 & 15 & 10.0 & 10.0 & 17.3 \\
\hline & 4.10 & 10 & 6.7 & 6.7 & 24.0 \\
\hline & 4.20 & 2 & 1.3 & 1.3 & 25.3 \\
\hline & 4.30 & 13 & 8.7 & 8.7 & 34.0 \\
\hline & 4.40 & 1 & 0.7 & 0.7 & 34.7 \\
\hline & 4.50 & 13 & 8.7 & 8.7 & 43.3 \\
\hline & 4.60 & 4 & 2.7 & 2.7 & 46.0 \\
\hline & 4.70 & 24 & 16.0 & 16.0 & 62.0 \\
\hline & 4.80 & 16 & 10.7 & 10.7 & 72.7 \\
\hline & 4.90 & 18 & 12.0 & 12.0 & 84.7 \\
\hline & 4,1 & 23 & 15.3 & 15.3 & 100.0 \\
\hline & Total & 150 & 100.0 & 100.0 & \\
\hline
\end{tabular}

\section{Variabel Kompetensi Pengajar}

Hasil jawaban responden tentang pernyataan yang diajukan pada variabel Kompetensi Pengajar berdasarkan hasil penelitian rata-rata keseluruhan variabel etos kerja ustadz/ustadzah sebesar 4,5 dengan prosentase 90,\% dengan kategori sangat baik.

Tabel Hasil Uji Variable sebagai berikut

\begin{tabular}{|r|r|r|r|r|r|}
\hline \multicolumn{2}{|c|}{} & Frequency & Percent & $\begin{array}{r}\text { Valid } \\
\text { Percent }\end{array}$ & \multicolumn{2}{c|}{$\begin{array}{c}\text { Cumulative } \\
\text { Percent }\end{array}$} \\
\hline \multirow{2}{*}{ Valid } & 3.70 & 1 & 0.7 & 0.7 & 0.7 \\
\cline { 2 - 6 } & 3.80 & 2 & 1.3 & 1.3 & 2.0 \\
\hline
\end{tabular}




\begin{tabular}{|l|l|r|r|r|r|}
\hline 3.90 & 5 & 3.3 & 3.3 & 5.3 \\
\cline { 2 - 6 } & 4,0 & 22 & 14.7 & 14.7 & 20.0 \\
\cline { 2 - 6 } & 4.10 & 9 & 6.0 & 6.0 & 26.0 \\
\cline { 2 - 6 } & 4.20 & 9 & 6.0 & 6.0 & 32.0 \\
\hline 4.30 & 9 & 6.0 & 6.0 & 38.0 \\
\cline { 2 - 6 } & 4.40 & 7 & 4.7 & 4.7 & 42.7 \\
\hline 4.50 & 10 & 6.7 & 6.7 & 49.3 \\
\cline { 2 - 6 } & 4.60 & 14 & 9.3 & 9.3 & 58.7 \\
\hline 4.70 & 12 & 8.0 & 8.0 & 66.7 \\
\cline { 2 - 6 } & 4.80 & 11 & 7.3 & 7.3 & 74.0 \\
\hline 4.90 & 17 & 11.3 & 11.3 & 85.3 \\
\hline 4.1 & 22 & 14.7 & 14.7 & 100.0 \\
\cline { 2 - 6 } & Total & 150 & 100.0 & 100.0 & \\
\cline { 2 - 6 } & & & & & \\
\hline
\end{tabular}

Dari hasil distribusi kuesioner tersebut dapat dilihat bahwa Kompetensi Pengajar paling banyak diangka 4,1 dan 4,0 masing-masing sebanyak 22 responden dan atau sebesar 14,7\%, lalu diangka 4,90 sebanyak 17 responden atau sebesar $11,3 \%$.

Setelah uji validitas dengan menggunakan 15 responden dan diketahui hasil item kuesioner yang valid dan tidak valid, item kuesioner yang valid akan digunakan untuk penelitian selanjutnya sedangkan yang tidak valid akan diperbaiki, maka kemudian disebarkan kuesioner tersebut ke 150 responden dan hasilnya dihitung dengan menggunakan bantuan program SPSS, maka didapatkan hasil sebagai berikut:

Tabel Validitas Kepemimpinan kyai

\begin{tabular}{|c|c|c|c|c|}
\hline \multicolumn{5}{|c|}{ Item-Total Statistics } \\
\hline & $\begin{array}{c}\text { Scale } \\
\text { Mean if Item } \\
\text { Deleted }\end{array}$ & $\begin{array}{c}\text { Scale } \\
\text { Variance if } \\
\text { Item Deleted }\end{array}$ & $\begin{array}{l}\text { Corrected } \\
\text { Item-Total } \\
\text { Correlation }\end{array}$ & $\begin{array}{l}\text { Cronbach's } \\
\text { Alpha if Item } \\
\text { Deleted }\end{array}$ \\
\hline $\mathrm{X} 1 \_1$ & 46.59 & 9.142 & 0.382 & 0.812 \\
\hline X1_2 & 46.49 & 9.017 & 0.511 & 0.800 \\
\hline $\mathrm{X} 1 \_3$ & 46.46 & 8.975 & 0.490 & 0.802 \\
\hline $\mathrm{X} 1 \_4$ & 46.67 & 8.586 & 0.544 & 0.796 \\
\hline $\mathrm{X} 1 \_5$ & 46.55 & 8.907 & 0.520 & 0.799 \\
\hline X1_6 & 46.53 & 8.949 & 0.515 & 0.800 \\
\hline $\mathrm{X} 1 \_7$ & 46.49 & 8.708 & 0.637 & 0.789 \\
\hline $\mathrm{X} 1 \_8$ & 46.74 & 8.663 & 0.433 & 0.810 \\
\hline X1_9 & 46.62 & 9.217 & 0.315 & 0.820 \\
\hline $\mathrm{X} 1 \_10$ & 46.55 & 8.880 & 0.530 & 0.798 \\
\hline $\mathrm{X} 1 \_11$ & 46.51 & 8.976 & 0.513 & 0.800 \\
\hline
\end{tabular}


Berdasarkan tabel diatas setelah melalui hasil pengolahan data melalui program SPSS untuk variabel kepemimpinan kyai, maka dapat diketahui dari 15 pernyataan diatas semuanya termasuk valid karena berada diatas nilai produk momen untuk 150 responden yaitu 0,159 , jadi $r$ hitung $>r$ tabel.

Tabel Validitas Etos kerja ustadz/ustadzah

\begin{tabular}{|c|c|c|c|c|}
\hline & \multicolumn{4}{|c|}{ Item-Total Statistics } \\
\hline & $\begin{array}{c}\text { Scale } \\
\text { Item } \\
\text { Deleted }\end{array}$ & $\begin{array}{c}\text { Scale } \\
\text { Variance if } \\
\text { Item Deleted }\end{array}$ & $\begin{array}{c}\text { Corrected } \\
\text { Item-Total } \\
\text { Correlation }\end{array}$ & $\begin{array}{c}\text { Cronbach's } \\
\text { Alpha if Item } \\
\text { Deleted }\end{array}$ \\
\hline X2_1 & 63.53 & 29.190 & 0.648 & 0.930 \\
\hline X2_2 & 63.57 & 28.717 & 0.731 & 0.928 \\
\hline X2_3 & 63.55 & 29.337 & 0.635 & 0.930 \\
\hline X2_4 & 63.62 & 28.801 & 0.650 & 0.930 \\
\hline X2_5 & 63.62 & 28.613 & 0.702 & 0.928 \\
\hline X2_6 & 63.63 & 28.222 & 0.703 & 0.928 \\
\hline X2_7 & 63.64 & 28.997 & 0.667 & 0.929 \\
\hline X2_8 & 63.71 & 27.897 & 0.689 & 0.929 \\
\hline X2_9 & 63.61 & 28.803 & 0.686 & 0.929 \\
\hline X2_10 & 63.66 & 29.045 & 0.639 & 0.930 \\
\hline X2_11 & 63.69 & 29.035 & 0.626 & 0.930 \\
\hline X2_12 & 63.53 & 29.096 & 0.666 & 0.929 \\
\hline X2_13 & 63.56 & 28.919 & 0.693 & 0.929 \\
\hline X2_14 & 63.55 & 28.894 & 0.702 & 0.928 \\
\hline X2_15 & 63.59 & 29.130 & 0.646 & 0.930 \\
\hline
\end{tabular}

Berdasarkan tabel diatas setelah melalui hasil pengolahan data melalui program SPSS untuk variabel etos kerja ustadz/ustadzah, maka dapat diketahui dari 15 pernyataan diatas semuanya termasuk valid karena berada diatas nilai produk momen untuk 150 responden yaitu 0,159 , jadi $r$ hitung $>$ r tabel.

Tabel Validitas Data X1

\begin{tabular}{|c|c|c|c|}
\hline $\begin{array}{c}\text { Item } \\
\text { Pernyataan }\end{array}$ & r hitung & r table & Validitas \\
\hline 1. & 0.382 & 0,159 & Valid \\
\hline 2. & 0.511 & 0,159 & Valid \\
\hline 3. & 0.490 & 0,159 & Valid \\
\hline 4. & 0.544 & 0,159 & Valid \\
\hline 5. & 0.520 & 0,159 & Valid \\
\hline 6. & 0.515 & 0,159 & Valid \\
\hline
\end{tabular}




\begin{tabular}{|c|c|c|c|}
\hline 7. & 0.637 & 0,159 & Valid \\
\hline 8. & 0.433 & 0,159 & Valid \\
\hline 9. & 0.315 & 0,159 & Valid \\
\hline 10. & 0.530 & 0,159 & Valid \\
\hline 11. & 0.513 & 0,159 & Valid \\
\hline
\end{tabular}

Tabel Validitas Data X2

\begin{tabular}{|c|c|c|c|}
\hline $\begin{array}{c}\text { Item } \\
\text { Pernyataan }\end{array}$ & r hitung & r table & Validitas \\
\hline 1. & 0.648 & 0,159 & Valid \\
\hline 2. & 0.731 & 0,159 & Valid \\
\hline 3. & 0.635 & 0,159 & Valid \\
\hline 4. & 0.650 & 0,159 & Valid \\
\hline 5. & 0.702 & 0,159 & Valid \\
\hline 6. & 0.703 & 0,159 & Valid \\
\hline 7. & 0.667 & 0,159 & Valid \\
\hline 8. & 0.689 & 0,159 & Valid \\
\hline 9. & 0.686 & 0,159 & Valid \\
\hline 10. & 0.639 & 0,159 & Valid \\
\hline 11. & 0.626 & 0,159 & Valid \\
\hline 12. & 0.666 & 0,159 & Valid \\
\hline 13. & 0.693 & 0,159 & Valid \\
\hline 14. & 0.702 & 0,159 & Valid \\
\hline 15. & 0.646 & 0,159 & \\
\hline
\end{tabular}

Tabel Deskriptif Statistik

\begin{tabular}{|c|c|c|c|}
\hline \multicolumn{4}{|c|}{ Descriptive Statistics } \\
\hline $\begin{array}{c}\text { Kepemimpinan } \\
\text { Kyai }\end{array}$ & Mean & Std. Devation & $\mathrm{N}$ \\
\hline $\begin{array}{c}\text { Etos Kerja } \\
\text { Ustadz/ustadzah }\end{array}$ & 61.22 & 3.254 & 150 \\
\hline $\begin{array}{c}\text { Kompetensi } \\
\text { Pengajar }\end{array}$ & 44.99 & 5.741 & 150 \\
\hline
\end{tabular}

Jumlah responden $\mathrm{N}$ adalah 150 orang, untuk menganalisis rata-rata hitung dari datadata diatas adalah mean, dan rata-rata yang dicapai siswa adalah 44,99. Standard deviasi adalah penyebaran berdasarkan akar dari varians menunjukkan keragaman kelompok data. Deviasi standard dari data di atas adalah 3,792. 
Uji Regresi Linier Berganda

Analisis regresi berganda bertujuan untuk mengetahui ada atau tidaknya pengaruh dua atau lebih variabel bebas $(\mathrm{X})$ terhadap variabel terikat $(\mathrm{Y})$. Uji t bertujuan untuk mengetahui ada atau tidaknya pengaruh parsial (sendiri) yang diberikan variabel bebas $(\mathrm{X}$ ) terhadap variabel terikat (Y). Uji f bertujuan untuk mengetahui ada atau tidaknya pengaruh simultan (bersama-sama) yang diberikan variabel bebas (X) terhadap variabel terikat (Y). Koefisien diterminasi berfungsi untuk mengetahui berapa persen pengaruh yang diberikan variabel bebas (X) terhadap variabel terikat (Y).

Untuk mengetahui apakah kepemimpinan kyai berpengaruh terhadap Kompetensi Pengajar dan etos kerja ustadz/ustadzah berpengaruh terhadap Kompetensi Pengajar, maka peneliti menggunakan bantuan program SPSS dengan hasil sebagai berikut :

\begin{tabular}{|c|c|c|c|c|c|c|c|}
\hline \multicolumn{8}{|c|}{ Coefficients $^{\mathrm{a}}$} \\
\hline \multirow{2}{*}{ Model } & \multicolumn{2}{|c|}{$\begin{array}{r}\text { Unstandard } \\
\text { ized Coefficients }\end{array}$} & \multirow{2}{*}{$\begin{array}{c}\text { Stand } \\
\text { ardized } \\
\text { Coefficien } \\
\text { ts } \\
\text { Beta }\end{array}$} & \multirow{2}{*}{$\mathrm{t}$} & \multirow{2}{*}{ ig. } & \multicolumn{2}{|c|}{$\begin{array}{l}\text { Collinearity } \\
\text { Statistics }\end{array}$} \\
\hline & B & $\begin{array}{l}\text { St } \\
\text { d. } \\
\text { Error }\end{array}$ & & & & $\begin{array}{l}\text { Toler } \\
\text { ance }\end{array}$ & IF \\
\hline $\begin{array}{l}\text { (Cons } \\
\text { tant) }\end{array}$ & $847^{8 .}$ & $546^{3 .}$ & & $495^{2 .}$ & $\begin{array}{l}0 \\
.014^{-1} \\
\end{array}$ & & \\
\hline $\mathrm{X} 1$ & $113^{0 .}$ & $076^{0 .}$ & 0.097 & $497^{1 .}$ & $.136^{0}$ & 0.764 & $.309^{1}$ \\
\hline $\mathrm{X} 2$ & $445^{0 .}$ & $043^{0 .}$ & 0.674 & $.392^{10}$ & $.000^{0}$ & 0.764 & $.309^{1}$ \\
\hline
\end{tabular}

Dasar pengambilan keputusan uji t adalah jika nilai signifikansi $<0,05$, maka terdapat pengaruh variabel $X$ terhadap variabel $Y$. Namun jika nilai signifikansi $>0,05$, maka tidak terdapat pengaruh variabel X terhadap variabel Y. Untuk variabel kepemimpinan kyai X1 nilai signifikansi 0,136 > 0,05, maka pengaruh variabel X1 terhadap variabel Y tidak terlalu signifikan dengan prosentase $11,3 \%$, Ho diterima dan Ha ditolak. Untuk variabel etos kerja ustadz/ustadzah X2 nilai signifikansi $0,000<0,05$, maka terdapat pengaruh variabel X2 terhadap variabel Y dengan prosentase $44,5 \%$, Ho ditolak dan Ha diterima.

Untuk mengetahui pengaruh kepemimpinan kyai dan etos kerja ustadz/ustadzah terhadap Kompetensi Pengajar secara bersamaan, maka peneliti menggunakan bantuan program SPSS dengan hasil sebagai berikut:

Tabel Anova

\begin{tabular}{|c|c|r|r|r|r|}
\hline \multicolumn{6}{|c|}{ ANOVA $^{\mathrm{a}}$} \\
\hline Model & $\begin{array}{c}\text { Sum of } \\
\text { Squares }\end{array}$ & $\mathrm{df}$ & $\begin{array}{c}\text { Mean } \\
\text { Square }\end{array}$ & $\mathrm{F}$ & Sig. \\
\hline
\end{tabular}




\begin{tabular}{|c|c|c|c|c|c|c|}
\hline \multirow{3}{*}{1} & Regression & 1130.598 & 2 & 565.299 & 82.081 & $.000^{\mathrm{b}}$ \\
\hline & Residual & 1012.396 & 147 & 6.887 & & \\
\hline & Total & 2142.993 & 149 & & & \\
\hline \multicolumn{7}{|c|}{ a. Dependent Variable: Y } \\
\hline \multicolumn{7}{|c|}{ b. Predictors: (Constant), X2, X1 } \\
\hline
\end{tabular}

Dasar pengambilan keputusan uji f adalah jika nilai signifikansi $<0,05$, maka terdapat pengaruh variabel X secara simultan terhadap variabel Y. Namun jika nilai signifikansi $>0,05$, maka terdapat pengaruh variabel X secara simultan terhadap variabel Y. Dari tabel di atas bahwa nilai signifikansi $0,000<0,05$, maka terdapat pengaruh secara simultan varibel $\mathrm{X}$ terhadap variabel Y, Ho ditolak dan Ha diterima.

Tabel Model Summary

\begin{tabular}{|c|c|c|c|c|c|}
\hline \multicolumn{6}{|c|}{ Model Summaryb } \\
\hline Model & $\mathrm{R}$ & $\begin{array}{r}\mathrm{R} \\
\text { Square }\end{array}$ & $\begin{array}{l}\text { Adjusted } \\
\text { R Square }\end{array}$ & $\begin{array}{c}\text { Std. } \\
\text { Error of the } \\
\text { Estimate }\end{array}$ & $\begin{array}{l}\text { Durbin- } \\
\text { Watson }\end{array}$ \\
\hline 1 & $.726^{a}$ & 0.528 & 0.521 & 2.624 & 1.995 \\
\hline \multicolumn{6}{|c|}{ a. Predictors: (Constant), X2, X1 } \\
\hline \multicolumn{6}{|c|}{ b. Dependent Variable: $Y$} \\
\hline
\end{tabular}

Berdasarkan tabel di atas bahwa R Square sebesar 0,528, hal ini mengandung arti bahwa pengaruh X1 dan X2 terhadap variabel Y adalah 52,8 \%.

\section{Interpretasi Hasil Penelitian}

Berdasarkan dari semua hasil uji hipotesis yang telah dilakukan melalui bantuan program SPSS, maka peneliti akan memaparkan hasil penelitian sebagai berikut :

1. $\mathrm{H} 1=$ Terdapat pengaruh yang tidak terlalu signifikan sebesar $11,3 \%$ kepemimpinan kyai (X1) terhadap Kompetensi Pengajar (Y), Ho diterima dan Ha ditolak.

2. $\mathrm{H} 2$ = Terdapat pengaruh $44,5 \%$ etos kerja ustadz/ustadzah (X2) terhadap Kompetensi Pengajar (Y), Ho ditolak dan Ha diterima.

3. $\mathrm{H3}=$ Terdapat pengaruh 52,8 \% kepemimpinan kyai (X1) dan etos kerja ustadz/ustadzah (X2) secara bersama-sama terhadap Kompetensi Pengajar (Y).

Dengan demikian bahwa Kepemimpinan Kyai di Pondok Pesantren Qotrun Nada Kota Depok tidak terlalu memberikan pengaruh terhadap Kompetensi Pengajar di Pondok Pesantren Qotrun Nada Kota Depok. Etos kerja ustadz/ustadzah Pondok Pesantren Qotrun Nada Kota Depok memberikan pengaruh terhadap Kompetensi Pengajar di Pondok Pesantren Qotrun Nada Kota Depok. Begitu pula kepemimpinan kyai dan etos kerja ustadz/ustadzah Pondok Pesantren Qotrun Nada Kota Depok memberikan pengaruh 52,8 \% terhadap Kompetensi Pengajar di Pondok Pesantren Qotrun Nada Kota Depok.

Berdasarkan pemaparan di atas menunjukkan bahwa kepemimpinan kyai dan etos kerja ustadz/ustadzah dapat mempengaruhi Kompetensi Pengajar di Pondok Pesantren Qotrun Nada Kota Depok, memungkinkan juga bahwa ada faktor lain yang dapat mempengaruhi 
Kompetensi Pengajar. Dalam hal ini maka pimpinan Pondok Pesantren Qotrun Nada di Depok diharapkan dapat terus memberikan yang terbaik, senantiasa belajar dari apa yang seharusnya diperbaiki dan menjadi kekurangan serta harus mampu memotivasi dan membina hubungan baik terhadap orang lain.

\section{E. KESIMPULAN}

Berdasarkan hasil analisa dan pembahasan maka dapat disimpulkan sebagai berikut :

1. Pengaruh antara kepemimpinan kyai dengan Kompetensi Pengajar di Pondok Pesantren Qotrun Nada Depok berdasarkan hasil penelitian maka hasilnya tidak begitu berpengaruh. Hal ini dibuktikan dengan nilai signifikansi 0,136 >0,05, maka tidak terdapat pengaruh. Ho diterima Ha ditolak.

2. Pengaruh antara etos kerja ustadz/ustadzah dengan Kompetensi Pengajar di Pondok Pesantren Qotrun Nada berdasarkan hasil penelitian maka hasilnya ada pengaruh positif. Hal ini dibuktikan dengan nilai signifikansi $0,000<0,05$, maka terdapat pengaruh. Ho ditolak Ha diterima.

3. Ada pengaruh yang signifikan antara kepemimpinan kyai dan etos kerja ustadz/ustadzah secara bersamaan terhadap Kompetensi Pengajar di Pondok Pesantren Qotrun Nada Depok. Hal ini dibuktikan dengan uji f nilai sinifikan 0,000< 0,05 , maka terdapat pengaruh. Begitu pula dengan nilai R Square 52,8\% termasuk kategori nilai yang kuat.

Selain dari kepemimpinan kyai dan etos kerja ustadz/ustadzah terhadap Kompetensi Pengajar, ada faktor lain yang dapat mempengaruhi Kompetensi Pengajar diantaranya menurut I Putu Ayub Darmawan (2017:27) yaitu : (1) Pengalaman Mengajar, (2) Jenjang Pendidikan dan Pelatihan, (3) Lesson Study, (4) Supervisi dan Kepemimpinan Kepala Sekolah, (5) Minat dan Motivasi Guru.

\section{REKOMENDASI}

Berdasarkan hasil penelitian yang telah dilakukan, maka terdapat beberapa hal yang akan direkomendasikan oleh peniliti, dalam rangka meningkatkan Kompetensi Pengajar Pondok Pesantren Qotrun Nada Depok diantaranya :

1. Pimpinan Pesantren / Kyai dalam penelitian ini bukan tidak memiliki pengaruh namun Kyai membutuhkan sandingan agar berpengaruh terhadap kompetensi pengajar, karena jika saja kyai memiliki kemampuan memimpin namun dari unsur ustadz/ustadzahnya tidak memiliki etos kerja pun hasilnya tidak akan maksimal. Oleh karenanya kyai pun dituntut untuk dapat meningkatkan kualitas kepemimpinnya dalam seluruh aspek seperti bagaimana memotivasi ustadz/ustadzah agar dapat menjalankan tugas dan kewajibannya.

2. Pengajar hendaknya lebih meningkatkan dalam menjalankan tugas pokok dan fungsi Pengajar, serta lebih memperkaya diri baik dalam aspek pedagogik, sosial, kepribadian maupun aspek professional seorang pengajar. Dengan harapan melalui sikap tersebut akan dapat lebih berpengaruh terhadap kompetensi pengajar. 
Selain memaparan di atas, peneliti berharap kepada para peneliti dibidang pendidikan dapat melakukan penelitian lanjutan dan mencari variabel-variabel lain, yang diduga

memiliki korelasi dengan prestasi belajar sehingga menjadi rujukan untuk meningkatkan prestasi belajar.

\section{DAFTAR PUSTAKA}

Anoraga,Pandji, 2000. Manajemen Bisnis, cet. Kedua, Jakarta: PT. Rineka Cipta. Arikunto, Suharismi, 2010. Metodologi Penelitian, Jakarta: Rineka Cipta.

Arsip Pondok Pesantren Qotrun Nada, Profil Pondok Pesantren Qotrun Nada, (Dilihat 15 Agustus 2019).

Imron, Arifin, 1993. Kepemimpinan Kiyai: Kasus Pondok Pesantren Tebu Ireng, Malang: Kalimashada Press.

Mulyasa, E. 2013. Standar Kompetensi dan Sertifikasi Pengajar, Bandung: PT. Remaja Rosdakarya.

Rochidin, Wahab, 2004. Sejarah Pendidikan Islam di Indonesia, Bandung: Alfabeta CV.

Salim, Petter dan Yenny Salim, 2002. Kamus B.I Kontemporer, Jakarta : Modern English Press, Edisi 3.

Sugiono, 2017. Metode Penelitian, Bandung:Alfabeta.

Suprahatiningkrum, Jamil, 2014. Pengajar Profesional : Pedoman Kinerja, Kualifikasi dan Kompetensi Pengajar, Yogyakarta: Ar Ruzz Media.

Tasmara, Toto, 1995. Etos Kerja Pribadi Muslim, Jakarta : Dana Bakti Wakaf.

Undang-Undang Republik Indonesia Peraturan Pemerintah No 14 Tahun 2005 tentang Standar Nasional Pendidikan. 